\title{
DIAGNOSING LEVELS OF DANCE COMPOSITION SKILLS IN THE STUDY PROCESS
}

\section{SUMMARY}

Introduction. Both the rapid cultural processes in the world and in Europe and the high empirical level of the art activities in the society have developed preconditions for the analysis of dance composition in the correlation between theoretical and empirical findings (Луговая, 2008). It has cleared the way to the research of dance composition skills within the study process. Development of dance composition skills is one of the most significant tasks of the study process in the education of dance teachers and choreographers. It stimulates personality development and creative skills of students in the development of socially significant art objects. Diagnosing levels of dance compositions skills gives wide possibilities for the development of such skills by using the experience and abilities of each individual student.

The Aim of the Study. To develop an approach of diagnosing levels of dance composition skills based on the developed dance composition structure, grounded in theory and practice in order to ensure a targeted organization of the study process.

Materials and Methods. Theoretical methods: analysis of scientific literature. Empirical methods: analysis of students' creative work, pedagogical observation. Processing of the statistical data.

Results. An approach to the diagnosis of dance composition skills during the study process based on theory and practice.

Conclusions. By analyzing the conducted experiment we can conclude that with the help of skill diagnosis one can:

1) Discover the development level of skills in various study stages;

2) Establish the development of dance composition skills from the reproductive to the productive level.

Diagnosing the levels of dance composition skills makes the study process targeted, stimulates the development of students' individual abilities.

Keywords: dance composition structure, skill levels, study process

\section{INTRODUCTION}

Development of dance composition skills is one of the most significant tasks of the study process in the education of dance teachers and choreographers. Knowledge and skills in dance composition are the makers of a purposeful activity of dance teachers and choreographers, they bring out the artistic potential, they stimulate the activity of a creative personality, although 'the creation of a work of art is just as mysterious as the creation of the world' (Freiberga, 2000). By addressing the possibilities of diagnosing dance composition skills within the study process, other problems connected to dance composition assessment in Latvia are activated - development of objective dance assessment criteria for dance competitions and shows in Latvia.

\section{THE AIM OF THE STUDY}

To develop an approach of diagnosing levels of dance composition skills based on the developed dance composition structure, grounded in theory and practice in order to ensure a targeted organization of the study process.

\section{MATERIALS AND METHODS}

1. Analysis of theoretical-scientific literature (dance philosophy, theory, history);

2. Empirical: analysis of students' creative work (discussions, self-reflection, analysis of video information), a pedagogical observation; 
3. Statistical and mathematical analysis of data. Calculation of the correlation coefficient by using SPSS 10.1 statistical data processing program.

In the $20^{\text {th }}$ century theory of dance composition develops in Europe owing to the dance systemization and notation developed by the theorist and choreographer R. Laban (Oxford Dictionary of Dance, 2004). Laban grounds the universal bodily positions in time and space, thus coming to an important conclusion that it is possible to widen the opportunities of dance composition by using a rhythmically dynamic and stereometrical concept of a dance structure. Laban's movements, concepts of time and space conclude the historical evolution of the development of compositional elements by granting them a scientific view and by creating the preconditions for the understanding of a dance composition as a united structure (Laban, 1966). Laban's ideas are later developed in the works of dance theorists: J. Deborah's research Time and the Dancing Image, E. R. Hayes' Dance Composition and Production, J. Smith-Autard's work Dance Composition etc. Laban's followers choreographers K. Jooss, J. Robbins, M. Cunningham, I. Kilian etc. develop Laban's conceptual approaches in practice by making use of them in their artistic activity. Rita Spalva in her doctoral work Development of Dance Composition Skills in the Artistic Activity of Students, based in the abovementioned experience in dance theory has developed and substantiated the compositional structure of dance, the five basic structural components of which are mutually interacting and the activity of each structural component is connected to others. The developed dance composition structure has structured a systemic approach to dance composition acquisition and has justified dance composition skill development as a purposeful activity. "A skill - an ability to conduct a particular acitivity according to the required quality and volume determined in the preconditions of the completion of the activity. A certain level of knowledge and technique acquisition that allows to make use of the acquired knowledge in a purposeful activity" (Pedagogijas terminu skaidrojošā vārdnīca, 2000). Žogla improves the definition with the cognition that "... a skill is an ability to act based on knowledge in order to reach a goal within concrete circumstances and by choosing a particular form" (Žogla, 2001). Development of dance composition as a specific type of artistic activity determines dance composition skills as "... a type of activity determined by the contents of structural components and dance image" (Spalva, 2007). J. Smith-Autard emphasizes that during the study process of composition the so called search for the 'midway' takes place, by midway meaning the transference of knowledge obtained through art education to the learnable skills. Within the acquisition process of dance composition, skills develop from nonstandard situations in a particularly organized way with the help of creative exercises that develop knowledge, simulate students' activity and independence. J. Smith-Autard states that the basic skills of dance composition are to develop, to stage and to evaluate a composition (SmithAutard, 1992). The scientist's approach is reflected in Picture 1 developed by the author.

Picture 1. Basic skills in dance composition

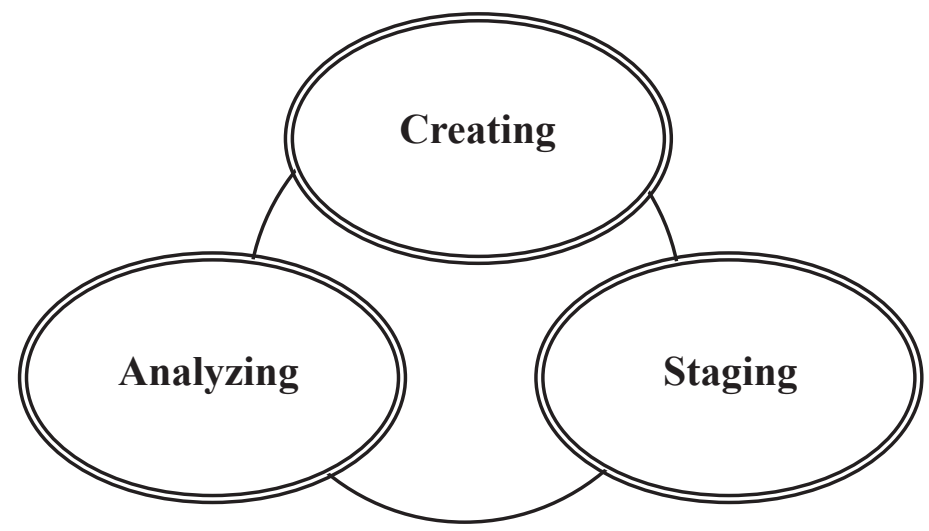


By starting the study course Dance Composition, students usually have different levels of knowledge and skills. In order to purposefully develop each student's skills in dace composition a diagnosis of student skill development levels is necessary both at the beginning of the studies and during the study process. In Spalva's doctoral work Development of Dance Composition Skills in the Artistic Activity of Students three dance composition skill levels are established: lower (reproductive), medium (interpretive), and higher (productive), along with their criteria and indicators. The criteria are developed by the contents of dance composition structural components, and its indicators are based on the dance composition skill characteristics developed in the doctoral thesis. Table 1 reflects the acquisition criteria and indicators of two general structural components - time and space.

Table 1. Skill development criteria and indicators of the use of time and space in dance composition (Spalva, 2007)

\begin{tabular}{|c|c|c|c|}
\hline \multirow{2}{*}{ Criteria } & \multicolumn{3}{|c|}{ Indicators } \\
\cline { 2 - 4 } & Level 1 (reproductive) & $\begin{array}{c}\text { Level 2 } \\
\text { (interpretive) }\end{array}$ & $\begin{array}{c}\text { Level 3 } \\
\text { (productive) }\end{array}$ \\
\hline 1. Skill to use rhythm & Detects monorhythm & $\begin{array}{c}\text { Detects monorhythm Partially } \\
\text { understands polyrhythm }\end{array}$ & $\begin{array}{c}\text { Detects and acts in } \\
\text { polyrhythm }\end{array}$ \\
\hline 2. Skill to use space & $\begin{array}{c}\text { Develops a symmetrical } \\
\text { layout of spatial action }\end{array}$ & $\begin{array}{c}\text { Develops a symmetrical and } \\
\text { an assymetrical spatial layout } \\
\text { Understands the vertical and } \\
\text { the horizontal line }\end{array}$ & $\begin{array}{c}\text { Understands the levels and } \\
\text { the sense of space, new } \\
\text { solutions observed }\end{array}$ \\
\hline
\end{tabular}

\section{RESULTS}

In order to test the development dynamics of dance composition skills in the study process an empirical research was conducted within the RTTEMA professional Bachelor's program Dance and Rhythmic Teacher between September 2008 and December 2008. The experimental group included 17 students of the fourth year. In the beginning of the experiment the development of skills was tested by conducting the so called initial test. In order to diagnose levels of skill development, several exercises were developed based in the criteria and indicators of dance composition skills. First eligibility criterion can be found by studying experiment participant's sense of rhythm, understanding of monorhythm and polyrhythm as well as the participant's activity during completion of the task. Second eligibility criterion is found by examining each individual's orientation skills in a space, the ability to make use of symmetric and asymmetric activity in a space, the ability to participate in the artistic process and to analyze it. In order to determine the results use was made of the observation method and analysis of students' activity. Task completion results were assessed with a grade by the pedagogue, by indicating the adequacy of experiment participants to the lower level with a 0 , average level with a 1 , higher level with a 2 . Results show that at the start of the experiment $20 \%$ of participants have a reproductive level of skill development, $47 \%$ of participants have an interpretative level of skill development, $24 \%$ of participants have a productive level of skill development (see Picture 2).

During the semester, two sets of exercises developed by the pedagogue were approbated, and the level of exercises determined the acquisition quality of each structural component. The obtained results were mathematically analyzed and a diagram was obtained which characterizes the level of dance composition skill development of each participant. By processing the data correlation coefficients and regression line graphs were obtained that indicate the acquisition of dance composition skills within each structural component. 


\section{Correlations}

\begin{tabular}{|c|c|c|c|}
\hline & & $\begin{array}{c}\text { Class A } \\
\text { average } \\
\text { result } \\
\text { of } 3 \\
\text { tests }\end{array}$ & $\begin{array}{c}\text { Class A } \\
\text { result } \\
\text { of final } \\
\text { test }\end{array}$ \\
\hline $\begin{array}{l}\text { Class A } \\
\text { average } \\
\text { result of } \\
3 \text { tests }\end{array}$ & $\begin{array}{l}\text { Person correlation } \\
\text { Sig (2-tailed) } \\
\text { N }\end{array}$ & $\begin{array}{c}1 \\
17\end{array}$ & $\begin{array}{c}.407 \\
.105 \\
17\end{array}$ \\
\hline $\begin{array}{l}\text { Class A } \\
\text { result of } \\
\text { final test }\end{array}$ & $\begin{array}{l}\text { Person correlation } \\
\text { Sig (2-tailed) } \\
\text { N }\end{array}$ & $\begin{array}{l}.407 \\
.105 \\
17\end{array}$ & $\begin{array}{c}1 \\
. \\
17\end{array}$ \\
\hline
\end{tabular}

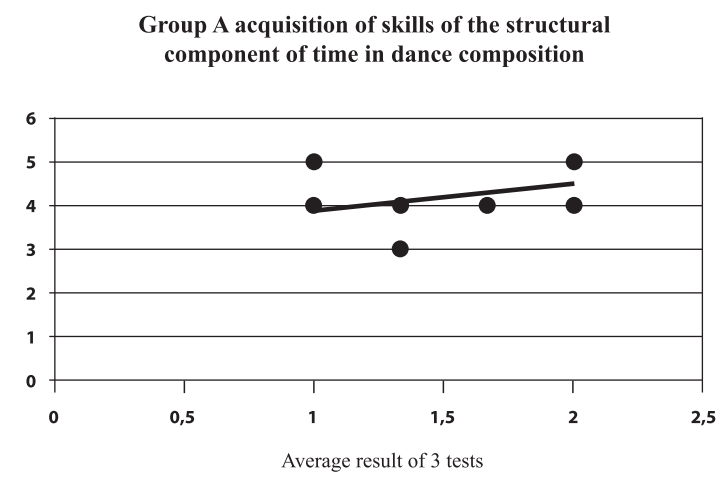

Picture 2 shows that each participant's correlation coefficient $\mathrm{R}$ is 0.407 and the regression line is fairly parallel to the $\mathrm{x}$ axis. Therefore an average correlation exists between the conditions that encourage the acquisition of the skills of the structural component of time and between the level of skills achieved by participants.

\section{Picture 3. Correlation coefficient and regression line testing the skills of the structural Correlations

\begin{tabular}{|c|c|c|c|}
\hline & & $\begin{array}{c}\text { Class A } \\
\text { average } \\
\text { result } \\
\text { of } 3 \\
\text { tests }\end{array}$ & $\begin{array}{c}\text { Class A } \\
\text { result } \\
\text { of final } \\
\text { test }\end{array}$ \\
\hline $\begin{array}{l}\text { Class A } \\
\text { average } \\
\text { result of } \\
3 \text { tests }\end{array}$ & $\begin{array}{l}\text { Person correlation } \\
\text { Sig (2-tailed) } \\
\text { N }\end{array}$ & $\begin{array}{c}1 \\
\dot{17}\end{array}$ & $\begin{array}{c}.679 \\
.003 \\
17\end{array}$ \\
\hline $\begin{array}{l}\text { Class A } \\
\text { result of } \\
\text { final test }\end{array}$ & $\begin{array}{l}\text { Person correlation } \\
\text { Sig (2-tailed) } \\
\text { N }\end{array}$ & $\begin{array}{l}.679 \\
.003 \\
17\end{array}$ & $\begin{array}{c}1 \\
. \\
17\end{array}$ \\
\hline
\end{tabular}

Group A - acquisition of spatial structuring skills in dance composition

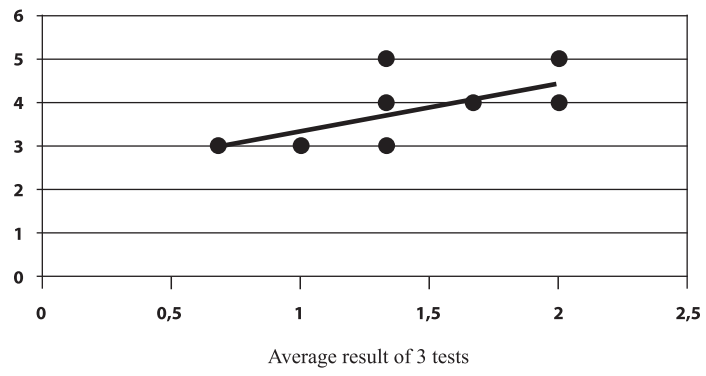

Picture 3 shows that group participants' correlation coefficient $\mathrm{R}$ is 0.679 and that the regression line is rather sheer. Therefore there exists an averagely high correlation between conditions encouraging the acquisition of skills and the achieved skill level of participants.

In the end of the experiment the results of skill development were tested by conducting the so called conclusion test. Its results reflect the students' ability to make use of structural components of dance composition. In order to perform the test participants generate a compositional idea and a topic, they develop a compositional plan, they choose music according to the compositional contents and form. Participants develop and choose means of expression of the composition by using the obtained dance composition skills; they look for optimal solutions of their use. The developed staging is demonstrated to the audience and filmed, analyzed and 
assessed from the point of view of the use of isolated structural components. Data obtained as a result of the analysis characterize the situation at the end of the experiment. For the analysis of results use is made of the previously described methodology.

\section{Picture 4. Indicators of dance composition skill development in the beginning and at the end of the experiment}

Group A in the beginning

of the Experiment

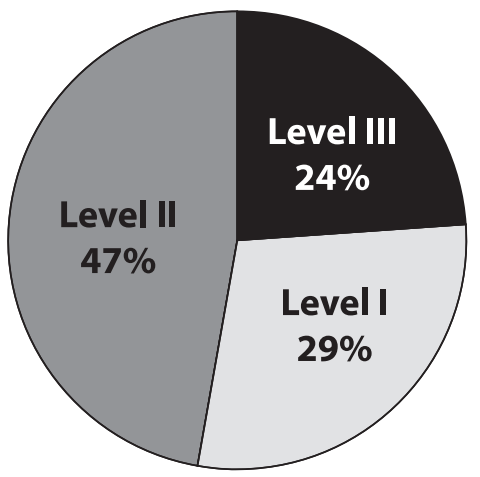

Group A in the end

of the Experiment

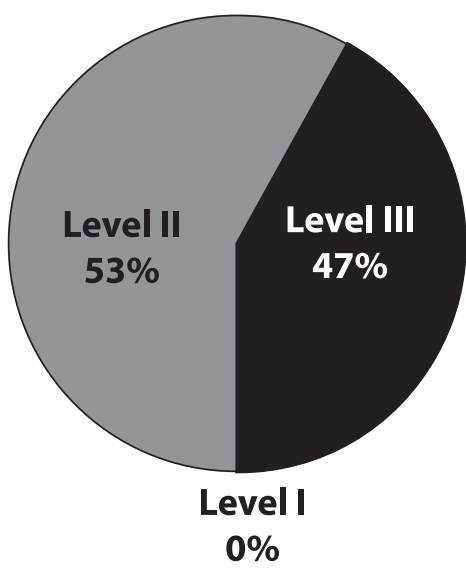

\section{CONCLUSIONS}

The research shows that in the initial, lower level of the experiment there are $29 \%$ of students, however in the end there are no students on this level. In return the amount of students who have reached the second level of skill development has increased (from $47 \%$ in the beginning of the experiment to $53 \%$ at the end of the experiment). The number of students who have reached the third level of skill development has also increased (from $24 \%$ in the beginning of the experiment to $47 \%$ at the end of the experiment, see Picture 4 ). Therefore during the experiment the level of students' compositional skills has increased and this has been stimulated by the theory-based exercise system introduced into the study process and a diversity in the organization of the study process.

By analyzing the conducted experiment we can conclude that with the help of skill diagnosis one can:

1. Discover the development level of skills in various study stages;

2. Establish the development of dance composition skills from the reproductive to the productive level.

Diagnosing the levels of dance composition skills makes the study process targeted, stimulates the development of students' individual abilities.

\section{REFERENCES}

1. Freiberga, E. (2000) Estētika. Mūsdienu estētikas skices. Rīga: Zvaigzne, 9. lpp.

2. Laban, R. (1966) Choreutics. London: Macdonald\&Evans, 278 p.

3. Oxford Dictionary of Dance (2004)//D.Craine,J.Mackrell, Oxford: University Press, p. 282-283.

4. Pedagogijas terminu skaidrojošā vārdnīca (2000) Rīga: Zvaigzne ABC, 134. lpp. 
5. Smith-Autard, J. (1992) Dance Composition. London: A\&C Black, p. 12.

6. Spalva, R. (2007) Dejas kompozīcijas prasmju attīstība studentu mākslinieciskajā darbībāa. Rīga: LU, 90. lpp.

7. Žogla, I. (2001) Didaktikas teorētiskie pamati. Rīga: RaKa, 224 lpp.

8. Луговая, Е. К. (2008) Философия танца. Санкт-Петербургский университет, с. 4.

Asoc. prof. Dr. paed. Rita Spalva

Riga Teacher Training and Educational Management Academy

Address: Andromedas gatve 10-31, Rīga LV-1084, Latvija

Fax: +37167808034

Mob. phone: +37129455831

E-mail: rita.spalva@rpiva.lv 